Open Access

\title{
Towards a motivational design? Connecting gamification user types and online learning activities
}

\author{
Klaudia Bovermann ${ }^{1^{*}}$ (D) and Theo J. Bastiaens ${ }^{2}$
}

\author{
* Correspondence: klaudia. \\ bovermann@fernuni-hagen.de \\ ${ }^{1}$ FernUniversität in Hagen, \\ Universitätsstraße 33, 58084 Hagen, \\ Germany \\ Full list of author information is \\ available at the end of the article
}

\begin{abstract}
Motivation is a crucial factor for students' learning behavior and plays a key role in the concept of gamification to foster students' motivation through specific gamification mechanics and elements. User types for gamification and associated gamification mechanics can classify students' interests and learning preferences and provide explanations for their motivational learning behavior. This study investigated how five gamification user types may relate to six mainly used online learning activities in a distance online bachelor's and master's class in educational science through the use of a systematic approach. A total of 86 students participated in the questionnaire in a cross-sectional study. The findings showed average agreement shares for all five gamification user types. The correlations revealed that the six online learning activities were at least significantly connected to one of the five gamification user types, and both person-centered and environment-centered perspectives were displayed. Finally, the results were discussed, and implications were derived for a motivational design.

Keywords: Gamification, Motivation, Motivational design, Distance education
\end{abstract}

\section{Introduction}

In educational settings, students' motivation is always a crucial factor that must be addressed. It is especially recognized in online and distance learning (Hartnett, 2016, 2019; Kim \& Frick 2011), as dropout rates are high compared to the rates in traditional face-to-face learning (Glass, 2014; Simpson 2013; Vogel et al. 2018). Therefore, motivation was identified in former studies as one of most important success factors in distance education (e.g. Bekele 2010; Hartnett 2016, 2019; Paterson 2014). However, as the number of online courses continues to increase (Allen \& Seaman 2017; Qayyumn \& Zawacki-Richter 2019), it comes increasingly pressing to counteract the high drop-out rates.

Students in online distance learning tend to be heterogeneous in that they vary widely not only in age and profession but also in learning goals and learning preferences (Koper 2015). Schell (2015) emphasized that it is important to "know what your audience likes and does not like" (p. 116). For educational settings, it is important to consider the needs, interests, experiences or preferences of the student "audience" (Kahan, Soffer \& Nachmias 2017; Park \& Choi 2009). This is a substantial aspect especially when looking at a heterogeneous group of distance learners to be able to support them with suitable motivational strategies in online learning platforms.

(c) The Author(s). 2020 Open Access This article is distributed under the terms of the Creative Commons Attribution 4.0 International License (http://creativecommons.org/licenses/by/4.0/), which permits unrestricted use, distribution, and reproduction in any medium, provided you give appropriate credit to the original author(s) and the source, provide a link to the Creative Commons license, and indicate if changes were made. 
Gamification is a new concept and is said to foster students' motivation (e.g. Alsawaier 2018; Dichev \& Dicheva 2017; Dreimane 2019; Hakulinen, Auvinen \& Korhonen 2015; Hamari 2015; Koivisto \& Hamari 2019; Pechenkina, Laurence, Oates, Eldridge \& Hunter 2017; Sailer \& Homner 2019; Utomo \& Santoso 2015). This concept with its associated game mechanics was considered in this survey to foster students' learning motivation. The investigation targeted distance learners in higher education who were enrolled in bachelor's and master's degree programs in educational science. The aim of this study was first to explore what kind of gamification user types (Marczewski 2015) and associated gamification mechanics could be revealed in this context. Then, in the next step, the relation was investigated between the surveyed gamification user types and frequently used online learning activities in the learning management system "Moodle." Finally, we provided recommendations for a motivational design in online learning environments. The focus was on motivational design (Keller 2009) that would reflect a meaningful integration of gamification strategies in learning management systems in the distance education context. Developing strategies that include tools and activities is essential for helping students successfully pursue their learning goals (Keller 2009).

The challenge of independent and self-organized learning in distance education can often lead to a loss of motivation, which is reflected in higher drop-out rates compared to traditional courses of studies (Allen \& Seaman 2017; Vogel et al. 2018). To counteract this development, purposeful and motivational strategies aligned with the target group should benefit the students' learning process in distance education (Hartnett 2019). However, well-grounded knowledge about students' preferred learning behaviors to foster learning motivation is necessary to address this issue. Therefore, the purpose of this study was first to evolve a deeper understanding of students' learning preferences, interests, and needs in the distance education context. Gamification mechanics and associated user types were used because (1) they provided a suitable classification of the aspects investigated in this study and (2) they combined students' learning preferences with motivational aspects, as the concept of gamification provides a framework for motivation (Sailer, Hense, Mayr \& Mandl 2017). Then, the subsequent purpose of this study was to collect findings on how online learning activities in learning management systems can be better adapted to students' needs and interests to provide motivational online learning experiences. Since learning management systems are the main learning platforms in distance education, learning activities are of major relevance for easily engaging students in their learning environment and enhancing motivational learning behavior (Marczewski 2015; Ryan \& Deci 2017). To investigate the aligned research questions in this study, descriptive statistics were applied, and correlations for nonparametric tests were conducted. The correlation method used in this study supported the desired knowledge about the associations between the variables surveyed. The results were expected to provide evidence of motivational designs aligned to students' learning preferences, needs, and interests. Finally, practical implications were derived from the results that could help distance education practitioners make purposeful decisions on the design and implementation of motivational online strategies addressed to the target group.

\section{Framework}

Motivation

Gamification in educational contexts tends to look at learners' motivation, motivational learning behavior or engagement in activities. A well-known theory of human 
motivation and personality is the self-determination theory (SDT) of Deci and Ryan (1985, 1993), Ryan \& Deci 2017). In SDT, motivation means that people feel energized, activated, or inclined to engage (Ryan \& Deci 2000a). Since SDT represents a broad framework for human motivation and provides a metatheory for framing motivational studies (Deci \& Ryan 2019), this approach was used in this study. With respect to investigations of gamification efficacy, SDT has been frequently used as a framework for examining students' learning motivation and engagement (e.g. Bovermann, Weidlich \& Bastiaens 2018; Buckley, DeWille, Exton, Exton \& Murray 2018; Chapman \& Rich 2018; Dichev, Dicheva, Angelova \& Agre 2015; Karra, Karampa \& Paraskeva 2019; Koivisto \& Hamari 2019; Proulx, Romero \& Arnab 2017; Sailer \& Homner 2019; Saputro, Salam \& Zakaria 2017; van Roy \& Zaman 2018; van Roy \& Zaman 2019). The theory considers three essential psychological needs of human motivation: (1) autonomy, which refers to the need for freedom and having meaningful choices; (2) competence, which considers the desire to gain mastery and achievements; and (3) relatedness, which is the need to interact and to be connected to others. They are crucial for understanding the what (content) and why (process) of goal pursuit and goal-directed behavior (Deci \& Ryan 2000; Ryan \& Deci 2000b). Their satisfaction is necessary for power or effectiveness and provides explanations for motivational behavior (Deci \& Ryan 2000; Ryan \& Deci 2000b). The most basic distinction in SDT is between intrinsic motivation and extrinsic motivation. Intrinsic motivation refers to doing activities because of interest or enjoyment. Extrinsic motivation refers to doing activities because of an obligation to avoid undesirable consequences (e.g., failing personal goals). Intrinsic autonomous motivation is considered to be the most beneficial type of motivation, with a high level of fulfillment of the three psychological needs (Deci \& Ryan 2000) and high-quality learning (Deci \& Ryan 1985, 1993; Ryan \& Deci 2017).

As in SDT, Pink (2012) also distinguishes between intrinsic and extrinsic motivation and considers three basic needs that are essential for intrinsic motivation. He identified (1) autonomy, the desire to be self-directed; (2) mastery, which is similar to competence in SDT, with the need to keep improving at something; and (3) purpose, the need to produce something meaningful that serves something beyond ourselves. In the following, the term "competence" will be used in relation to SDT but includes "mastery" as well.

These four aspects, autonomy, competence, relatedness, and purpose, of the two motivation theories of SDT and Pink are the basis for the gamification user types and associated game mechanics (Marczewski 2015), which can explain students' motivational behavior. Findings in relation to online learning activities can contribute to designing motivational online learning environments (Keller 2009) and can help meet the needs of students to support their learning progress and behavior (Deci \& Ryan 1985).

\section{Gamification}

A very often used definition for gamification is "the use of game design elements in nongame contexts" from Deterding et al. (2011, p. 10). Kapp (2012, p. 10), who mentions the use of game mechanics to foster learners' motivation to promote learning, defines gamification as the use of "game-based mechanics, aesthetics, and game-thinking to engage people, motivate action, promote learning, and solve problems." These definitions with different concepts of game design or game design techniques illustrate that successful 
gamification is not simply applying game elements or game mechanics (Werbach \& Hunter 2012) but is rather a more holistic approach to game thinking (Kim 2018; Salen \& Zimmermann 2004; Werbach \& Hunter 2012). In the field of education, game thinking means solving problems with game-like concepts, looking at how learners can be motivated to create engaging learning environments and supporting students in their learning process. In addition, game thinking combines game design and design thinking to help build engaging experiences (Kim 2018).

In recent years, the concept of gamification has often been applied in educational contexts for different subjects, learning activities, educational levels, and various designs. However, the existing findings are still mixed and tend to be dependent on the context, population, or design (Dichev \& Dicheva 2017). Therefore, it is crucial to understand the target group with their unique learning preferences and to use a systematic approach towards a meaningful design.

\section{Game mechanics and user types for gamification}

Underlying all types of games are game mechanics. Similarly, game mechanics are the backbone of gamification and may help learners to achieve task performance (Scheiner \& Witt 2013). Game elements such as points, badges, and leaderboards (PBL; Werbach \& Hunter 2012) are used to reinforce particular learning behavior through their game mechanics (Werbach \& Hunter, 2012). Game mechanics are important for the procedures and rules in a game and describe the particular components to achieve a goal in a game (Salen \& Zimmermann 2004; Schell 2015). They afford players the ability to engage in various desired behaviors and generally support the overall dynamics of a game (Hunicke, Leblanc \& Zubek 2004; Salen \& Zimmermann 2004). Zichermann and Cunningham (2011) suggested various types of game mechanics that describe the interests and preferences of people to meet their needs in a game to support or maintain motivation. Additionally, Kapp (2014) emphasized the importance of game mechanics in online learning to consider an appropriate set of activities and patterns of actions that can lead to learning. It can be concluded that game mechanics are important strategies in gamified online learning to support learners' motivation and engagement in order to successfully perform online tasks (Scheiner \& Witt 2013). Current literature reviews have highlighted that game mechanics have a positive impact on students' motivation in online learning (Sailer et al. 2017; Saputro et al. 2017). The reviews have also documented the effects on students' learning outcomes and the key role of gamified designs (Alsawaier, 2018; Clark, Tanner-Smith \& Killingsworth 2016). Finally, studies have reported a positive effect of game mechanics on the motivation of students to become engaged in their tasks (Hew, Huang, Chu \& Chiu 2016; Huang et al. 2018).

Bartle (1996) developed a classification of player types for video games (Achievers, Explorers, Socializers, and Killers) that is based on a character theory of player styles. This classification gives rise to the notion that different people may enjoy different types (Kim 2014; Werbach \& Hunter 2012). Then, Kim (2014) enhanced Bartle's player types and adjusted the styles with social actions (Compete, Express, Collaborate, Explore). Similar to Bartle's and Kim's player types, Marczewski (2015) identified specific user types for gamification that are related to game mechanics on the basis of the psychological needs for intrinsic motivation. He referred to Zichermann and Cunningham (2011) for the suggested game mechanics and associated user types that he adopted for 
online learning. This approach has the advantage of systematically selecting the corresponding gamification user types and mechanics of the target group's learning preferences, interests, or experiences in connection with online learning activities. Since the present survey is based on these concepts, the term "game mechanics" now becomes "gamification mechanics" or "mechanics." Both terms will be used in the following.

Table 1 shows the related gamification user types and mechanics on the basis of the motivational concepts that were of relevance in this study (Deci \& Ryan 1985, 1993; Diamond, Nacke, Tondello, Tscheligi \& Marczewski 2015; Korbas 2015; Marczewski 2015; Pink 2012; Ryan \& Deci 2017). However, in this study, the gamification mechanics "Unlockables/Rare Content" and "Certificates" were matched to different user types than in the referred literature. This change was necessary for content-related reasons.

\section{Online learning activities in learning management systems}

Distance online institutions provide online learning management systems such as Moodle (2018) for students to have access to all relevant information for their courses of study. Such a learning management system is usually the key means by which online distance learners engage in online course activities and to have contact with their fellow students or instructors. Six possible online learning activities (A-F), which are frequently used in the Moodle learning environment of the courses of study surveyed (Moodle 2018), will be presented next.

(A) The activity "Forum" opens up space for discussions about learning content and allows students to exchange ideas by posting comments. In addition, images or videos can be shared and included in forum posts. (B) Students can submit their work to be reviewed by a peer or can review the work of fellow students with the activity "Peer Assessment." (C) Then, students can check their knowledge by using the activity "Quiz," which can be arranged with a variety of question types. (D) The activity "Task" is used

Table 1 Motivation or drive, user types for gamification, and associated mechanics

\begin{tabular}{|c|c|c|c|c|c|}
\hline \multicolumn{6}{|c|}{ Motivation and gamification user types and associated gamification mechanics* } \\
\hline $\begin{array}{l}\text { Motivation/ } \\
\text { drive }\end{array}$ & $\begin{array}{l}\text { Relatedness } \\
\text { (intrinsic) }\end{array}$ & $\begin{array}{l}\text { Autonomy } \\
\text { (intrinsic) }\end{array}$ & Competence (intrinsic) & Purpose (intrinsic) & Rewards (extrinsic) \\
\hline Definition & $\begin{array}{l}\text { The desire } \\
\text { to connect } \\
\text { to others. }\end{array}$ & $\begin{array}{l}\text { The need to } \\
\text { feel } \\
\text { independent } \\
\text { or free. }\end{array}$ & $\begin{array}{l}\text { The desire to learn } \\
\text { new skills and develop } \\
\text { expertise in them. }\end{array}$ & $\begin{array}{l}\text { A feeling of greater } \\
\text { meaning or a desire } \\
\text { to be altruistic. }\end{array}$ & $\begin{array}{l}\text { Receiving } \\
\text { acknowledgement. }\end{array}$ \\
\hline User type & $\begin{array}{l}\text { (1) Socializer } \\
\text { (So) }\end{array}$ & $\begin{array}{l}\text { (2) Free Spirit } \\
\text { (FS) }\end{array}$ & (3) Achiever (A) & $\begin{array}{l}\text { (4) Philanthropist } \\
\text { (Ph) }\end{array}$ & (5) Player (P) \\
\hline \multirow[t]{4}{*}{$\begin{array}{l}\text { Associated } \\
\text { gamification } \\
\text { mechanics }\end{array}$} & $\begin{array}{l}\text { Social } \\
\text { Discovery/ } \\
\text { Network } \\
\text { (So1) }\end{array}$ & $\begin{array}{l}\text { Creativity } \\
\text { (Tools) (FS1) }\end{array}$ & Level/Progression (A1) & Care-Taking (Ph1) & $\begin{array}{l}\text { Leaderboards/ } \\
\text { Ladders (P1) }\end{array}$ \\
\hline & $\begin{array}{l}\text { Guilds/ } \\
\text { Teams (So2) }\end{array}$ & $\begin{array}{l}\text { Exploration } \\
\text { (FS2) }\end{array}$ & $\begin{array}{l}\text { Learning/New Skills } \\
\text { (A2) }\end{array}$ & $\begin{array}{l}\text { Sharing Knowledge } \\
\text { (Ph2) }\end{array}$ & $\begin{array}{l}\text { (Virtual) Economy } \\
\text { (P2) }\end{array}$ \\
\hline & $\begin{array}{l}\text { Social } \\
\text { Pressure, } \\
\text { neg. (So3) }\end{array}$ & $\begin{array}{l}\text { Easter Eggs } \\
\text { (FS3) }\end{array}$ & Quests (A3) & $\begin{array}{l}\text { Meaning/ Purpose } \\
\text { (Ph3) }\end{array}$ & $\begin{array}{l}\text { (Physical) } \\
\text { Rewards/Prizes } \\
\text { (P2) }\end{array}$ \\
\hline & $\begin{array}{l}\text { Social } \\
\text { Pressure, } \\
\text { pos. (So4) }\end{array}$ & $\begin{array}{l}\text { Branching } \\
\text { Choices (FS4) }\end{array}$ & $\begin{array}{l}\text { Unlockables/ Rare } \\
\text { Content (A4) }\end{array}$ & $\begin{array}{l}\text { Collect and Trade } \\
\text { (Ph4) }\end{array}$ & $\begin{array}{l}\text { Badges/ } \\
\text { Achievements/ } \\
\text { Certificates (P4) }\end{array}$ \\
\hline
\end{tabular}

*e.g., Marczewski (2015); Salen and Zimmermann (2004); Zichermann and Cunningham (2011) 
for students to work on a problem either alone or in collaboration with others. (E) Using the activity "Tutorial" is a good way to explain content with (a set of) short videos. (F) Finally, the activity "Wiki" is a tool for online collaboration and provides a collection of authored web documents. All students can create content together, and wikis grow by adding pages.

The kind of online learning activity that is useful for the learning process of students depends on the learning goal and desired instruction. However, it is of interest for instructors to consider students' learning preferences and motivation to support involvement in online proposals (Werbach \& Hunter 2012), such as the presented activities $(\mathrm{A}-\mathrm{F})$.

\section{Research questions}

Until now, no research has been performed to systematically combine gamification user types and relevant gamification mechanics with typical online learning activities that can be provided in learning management systems such as Moodle (2018). In addition, little research has been conducted to understand learners and their learning contexts to improve designs for engaging learning experiences (e.g. Karunanayaka \& Naidu 2017; Naidu 2017). Furthermore, investigations of gamification in educational contexts are limited (Dreimane 2019), and implementation guidelines on gamified designs are still missing (Alsawaier 2018).

The following assumptions from the framework and current literature lead to research questions RQ (1)-(3): (1) First, to support students' motivation in an online distance learning course, it is useful to have more information about their learning preferences and interests. (2) User types for gamification and associated gamification mechanics capture this crucial issue to learn more about students' attitudes, personal drive, and motivation to make steps towards a personalized online learning experience. (3) Then, these insights can help to foster students' engagement in their online learning process. (4) Finally, the findings of this study may aid in taking steps towards a motivational design in online learning managements such as Moodle.

$R Q$ (1). What kinds of gamification user types can be identified for the context at hand, and how prevalent are they?

$R Q$ (2). How are the five gamification user types, their associated gamification mechanics and the six online learning activities related?

$R Q$ (3). What kind of motivational design is obtained for the gamification user types, gamification mechanics, and online learning activities?

\section{Methodology}

A cross-sectional study with an exploratory design was used. Data were collected between April 2018 and September 2018 with both a paper-and-pencil and an online questionnaire consisting of 26 items for quantitative analysis.

The questionnaire contained 20 questions for the gamification mechanics associated with the five gamification user types (Diamond et al. 2015; Korbas 2015; Marczewski 2015) (Table 2). The descriptions for (1) "Socializer (So)," (2) "Free Spirit (FS)," (3) "Achiever (A)," (4) "Philanthropist (Ph)," and (5) "Player (P)" contained four items each. Statements for the online learning activities were reported via a total of six questions 
Table 2 Questionnaire

\begin{tabular}{|c|c|c|}
\hline $\begin{array}{l}\text { Relation to user type } \\
\text { and motivation }\end{array}$ & Gamification mechanics & Question* \\
\hline \multirow[t]{4}{*}{$\begin{array}{l}\text { (1) Socializer } \\
\text { (So)_relatedness }\end{array}$} & $\begin{array}{l}\text { Social Discovery/Network } \\
\text { (So1) }\end{array}$ & I like to interact with others online. \\
\hline & Guilds/Teams (So2) & I like to achieve something together with others. \\
\hline & $\begin{array}{l}\text { Social Pressure (neg.) } \\
\text { (So3) }\end{array}$ & I always make sure to look good in front of others. \\
\hline & $\begin{array}{l}\text { Social Pressure (pos.) } \\
\text { (So4) }\end{array}$ & $\begin{array}{l}\text { I am more motivated, when others watch me doing } \\
\text { something. }\end{array}$ \\
\hline \multirow{4}{*}{$\begin{array}{l}\text { (2) Free Spirit } \\
\text { (FS)_-autonomy }\end{array}$} & Creativity (Tools) (FS1) & I am creative and like to create and design things. \\
\hline & Exploration (FS2) & I often spend a lot of time trying out things. \\
\hline & Easter Eggs (FS3) & $\begin{array}{l}\text { It gives me special pleasure when I can discover hidden } \\
\text { clues or allusions in a matter. }\end{array}$ \\
\hline & Branching Choices (FS4) & I like to choose from many possibilities. \\
\hline \multirow{4}{*}{$\begin{array}{l}\text { (3) Achiever } \\
\text { (A)_competence }\end{array}$} & Level/Progression (A1) & I like to see steady progress in the things I do. \\
\hline & Learning/New Skills (A2) & I am thirsty for knowledge and like to continue my training. \\
\hline & Quests (A3) & I like to work out things step by step. \\
\hline & $\begin{array}{l}\text { Unlockables/Rare } \\
\text { Content (A4) }\end{array}$ & $\begin{array}{l}\text { It motivates me to work towards a particular objective or } \\
\text { option. }\end{array}$ \\
\hline \multirow{4}{*}{$\begin{array}{l}\text { (4) Philanthropist } \\
\text { (Ph)_-purpose }\end{array}$} & Care-Taking (Ph1) & It makes me happy when I am able to help others. \\
\hline & Sharing Knowledge Ph2) & I like to share my knowledge with others. \\
\hline & Purpose/Meaning (Ph3) & $\begin{array}{l}\text { Things are important to me that have a deeper meaning or } \\
\text { benefit for the common good. }\end{array}$ \\
\hline & Collect and Trade (Ph4) & I enjoy collecting certain items (e.g., records, stamps, comics). \\
\hline \multirow[t]{4}{*}{$\begin{array}{l}\text { (5) Player } \\
\text { (P) -rewards }\end{array}$} & $\begin{array}{l}\text { Leaderboards/Ladders } \\
\text { (P1) }\end{array}$ & I often try to be the best in what I do. \\
\hline & (Virtual) Economy (P2) & $\begin{array}{l}\text { I weigh my actions objectively, so I always know how much I } \\
\text { invest and what I have to get. }\end{array}$ \\
\hline & $\begin{array}{l}\text { (Physical)Rewards/Prizes } \\
\text { (P3) }\end{array}$ & $\begin{array}{l}\text { When I participate in something, I focus on results and } \\
\text { rewards. }\end{array}$ \\
\hline & $\begin{array}{l}\text { Badges/Achievements, } \\
\text { Certificates (P4) }\end{array}$ & $\begin{array}{l}\text { It makes me especially proud when I receive a certificate or } \\
\text { award for a performance. }\end{array}$ \\
\hline
\end{tabular}

*Questions were based on Diamond et al. (2015), Korbas (2015), and Marczewski (2015)

and included items for (A) Forum, (B) Peer Assessment, (C) Quiz, (D) Task, (E) Tutorial, and (F) Wiki. A 4-point Likert scale (with 1 = strongly disagree, 2 = rather disagree, $3=$ rather agree and $4=$ strongly agree) was used to collect data. The middle category was omitted to gain meaningful information for interpreting the data (Döring \& Bortz 2016). The study investigated German online distance learners. For this reason, a German questionnaire (Korbas 2015) was applied. This questionnaire was constructed on the basis of Marczewski's gamification user types and associated gamification mechanics (Diamond et al. 2015; Marczewski 2015; Table 2) in German. Accordingly, these language advantages for the students surveyed led to this choice of application.

\section{Data analysis and results}

Descriptive statistics

In total, 650 students were enrolled in the courses of study, 350 students in the bachelor's degree program and 300 students in the master's degree program. In total, 86 
students participated in the online questionnaire. The majority of the students (53\%) reported being enrolled in the bachelor's degree program, and $44 \%$ indicated being enrolled in the master's degree program. Three percent did not specify their courses of study. In addition, more female than male students participated in the questionnaire. In the bachelor's degree program, $48 \%$ of the students were female, and $6 \%$ were male. In the master's degree program, $42 \%$ of the learners were female, and four percent were male. The master's program had the largest share of students aged between 18 and 40 . Then, 32\% of the learners who stated that they were older than 40 years were enrolled in the bachelor's degree program (Fig. 1).

$R Q$ (1). The average agreement with the items for gamification mechanics associated with the five gamification user types (Marczewski 2015) showed that the largest share was for the user type Achiever (26\%), followed by Philanthropist (23\%) Free Spirit (21\%) and Socializer (16\%). The smallest share was revealed for Player (14\%) (Fig. 2).

$R Q$ (2). Reliability testing for the items of gamification mechanics associated with the five user types showed that the value for Cronbach's alpha was not acceptable. Therefore, no scales for the items for the five user types were used. Instead, we applied tests for statistical correlations between all items of the gamification mechanics and online learning activities. The gamification mechanics remained assigned to the gamification user types. Correlations were analyzed with Pearson's correlation coefficient and SPSS V25, and the results are listed in Table 3.

Socializer. The gamification mechanic "Social Discovery/Network (So1)" is significant and positively correlated with the online learning activities of working in Forum, Peer Assessment, and Wiki $(r=.594, r=.397, r=.340, p<.05$, respectively). The correlation coefficients show a medium to strong correlation (Cohen 2009). A significant and positive correlation is also shown between Social Discovery/Network (So1) and the activities Task and Tutorial $(r=.255, r=.279, p<.05$, respectively). These correlations can be rated as small (Cohen 2009). In addition, the gamification mechanic "Guilds/Teams (So2)" revealed a significant and positive correlation with the online learning activities Peer Assessment and Wiki ( $r=.307, r=.232, p<.05$, respectively). These coefficients show a small to medium correlation (Cohen 2009). Finally, the mechanic "Social Pressure, pos." (So4) is significant and positively correlated to the online learning activity

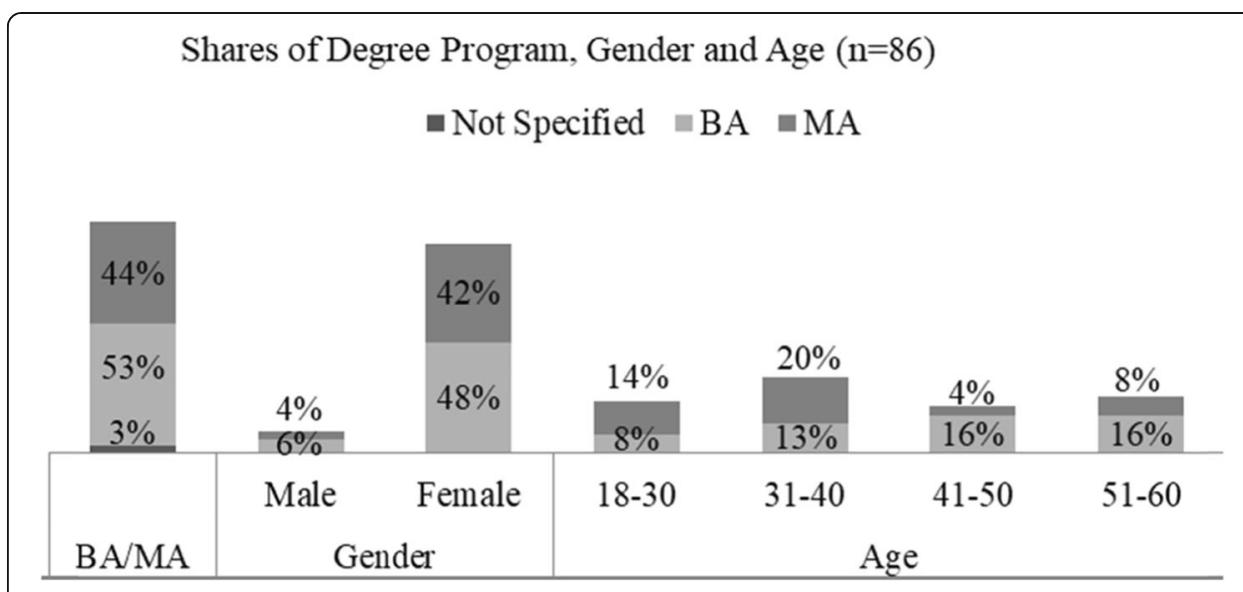

Fig. 1 Shares of degree program, gender, and age 


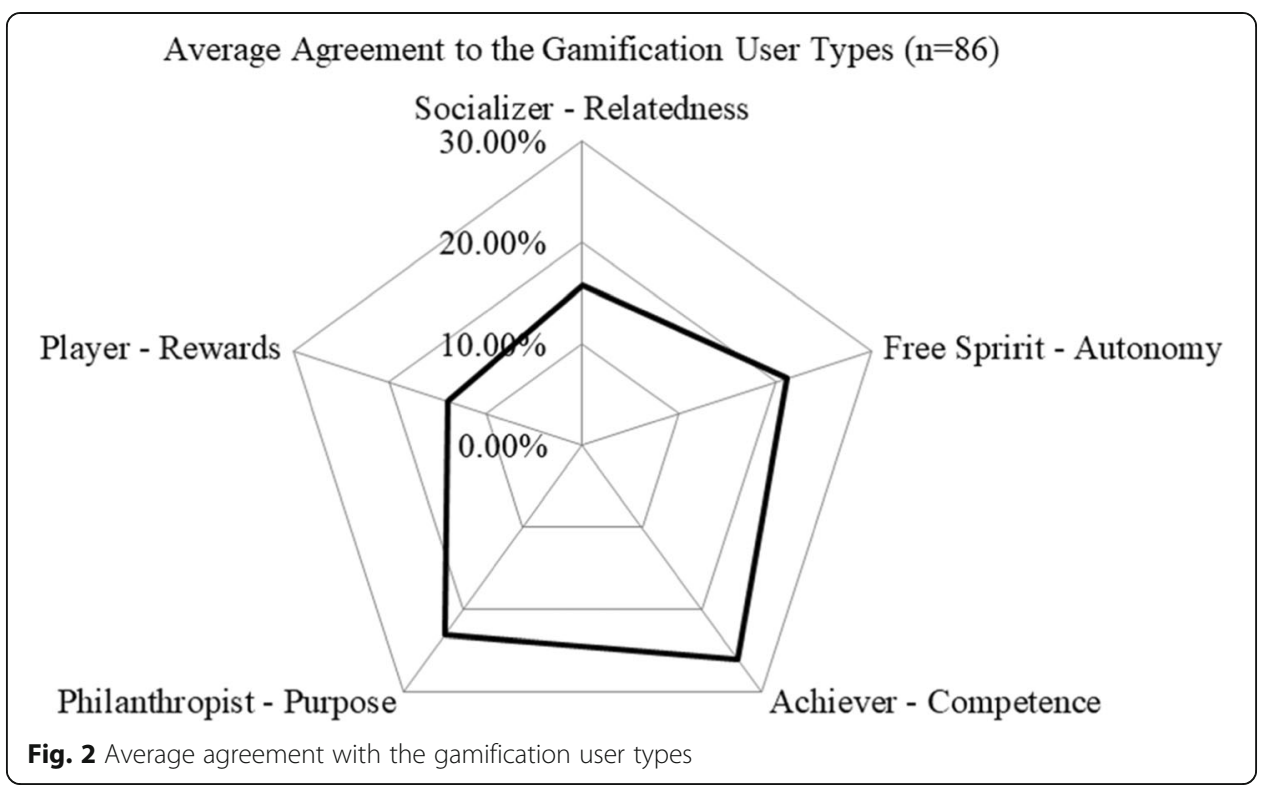

Table 3 Correlations between gamification user types, mechanics, and online learning activities ( $n$ $=86)$

\begin{tabular}{|c|c|c|c|c|c|c|c|}
\hline \multirow[t]{2}{*}{ User type } & \multirow[t]{2}{*}{ Gamification mechanics } & \multicolumn{6}{|c|}{ Online learning activities } \\
\hline & & $\begin{array}{l}\text { (A) } \\
\text { Forums }\end{array}$ & $\begin{array}{l}\text { (B) Peer } \\
\text { Assessment }\end{array}$ & $\begin{array}{l}\text { (C) } \\
\text { Quiz }\end{array}$ & $\begin{array}{l}\text { (D) } \\
\text { Task }\end{array}$ & $\begin{array}{l}\text { (E) } \\
\text { Tutorial }\end{array}$ & $\begin{array}{l}\text { (F) } \\
\text { Wiki }\end{array}$ \\
\hline \multirow[t]{4}{*}{$\begin{array}{l}\text { (1) Socializer- } \\
\text { relatedness }\end{array}$} & $\begin{array}{l}\text { Social Discovery/Network } \\
\text { (So1) }\end{array}$ & $.594^{*}$ & $.397^{*}$ & .019 & $.255^{*}$ & $.279^{*}$ & $340^{*}$ \\
\hline & Guilds/Teams (So2) & .184 & $.307^{*}$ & -.209 & .005 & .188 & $232^{*}$ \\
\hline & Social Pressure (neg.) (So3) & .081 & .045 & -.148 & .096 & .060 & -.054 \\
\hline & Social Pressure (pos.) (So4) & .177 & $.215^{*}$ & -.103 & .022 & .089 & -.009 \\
\hline \multirow{4}{*}{$\begin{array}{l}\text { (2) Free Spirit- } \\
\text { autonomy }\end{array}$} & Creativity (Tools) (FS1) & .202 & .180 & .008 & .045 & .113 & -.009 \\
\hline & Exploration (FS2) & .212 & .173 & $.275^{*}$ & .012 & .194 & -.003 \\
\hline & Easter Eggs (FS3) & -.091 & .043 & -.004 & -.078 & .042 & .000 \\
\hline & Branching Choices (FS4) & .118 & .070 & .088 & -.049 & .126 & -.186 \\
\hline \multirow{4}{*}{$\begin{array}{l}\text { (3) Achiever- } \\
\text { competence }\end{array}$} & Level/Progression (A1) & .163 & .043 & .117 & .170 & $.388^{*}$ & $.235^{*}$ \\
\hline & Learning/New Skills (A2) & .090 & .167 & .108 & .092 & .162 & $245^{*}$ \\
\hline & Quests (A3) & -.025 & .077 & -.095 & .080 & .070 & -.067 \\
\hline & $\begin{array}{l}\text { Unlockables/Rare Content } \\
\text { (A4) }\end{array}$ & .009 & .115 & .078 & .015 & $.243^{*}$ & .156 \\
\hline \multirow{4}{*}{$\begin{array}{l}\text { (4) Philanthropist- } \\
\text { purpose }\end{array}$} & Care-Taking (Ph1) & .014 & .013 & .074 & -.135 & $.215^{*}$ & .201 \\
\hline & Sharing Knowledge (Ph2) & $.309^{*}$ & $.262^{*}$ & .052 & .117 & .172 & $.257^{*}$ \\
\hline & Purpose/Meaning (Ph3) & .079 & -.006 & .011 & -.102 & $248^{*}$ & .162 \\
\hline & Collect and Trade (Ph4) & .177 & -.014 & -.013 & .081 & .125 & .136 \\
\hline \multirow[t]{4}{*}{ (5) Player-rewards } & Leaderboards/Ladders (P1) & -.056 & .045 & -.085 & -.077 & -.065 & -.026 \\
\hline & (Virtual)Economy (P2) & .109 & .159 & -.021 & $.213^{*}$ & -.010 & .084 \\
\hline & (Physical)Rewards/Prizes (P3) & .000 & .041 & -.114 & -.046 & .110 & .058 \\
\hline & $\begin{array}{l}\text { Badges/Achievements; } \\
\text { Certificates (P4) }\end{array}$ & .124 & -.026 & .073 & .078 & -.009 & .012 \\
\hline
\end{tabular}


Peer Assessment ( $r=.215, p<.05$, respectively), which shows a small effect (Cohen, 2009) (Table 3).

Free spirit. There is a significant and positive correlation between the gamification mechanic of "Exploration (FS2)" for the user type Free Spirit and the online activity Quiz ( $r=.275, p<.05$, respectively), which is a small to medium correlation (Cohen 2009) (Table 3).

Achiever. The variable "Level/Progression (A1)" is significant and positively correlated with the online learning activities Tutorial and Wiki $(r=.388, r=.235, p<.05$, respectively). Furthermore, there is a significant and positive correlation between the item "Learning/New Skills (A2)" and the activity Wiki $(r=.245, p<.05$, respectively). Finally, the gamification mechanic "Unlockables/Rare Content (A4)" shows a significant and positive correlation with the learning activity Tutorial $(r=.243, p<.05$, respectively). The coefficients for these correlations can be regarded as small to medium (Cohen 2009) (Table 3).

Philanthropist. The variable "Care-Taking (Ph1)" shows a significant and positive correlation with the online learning activity Tutorial $(r=.215, p<.05$, respectively), but the correlation is considered as low (Cohen 2009). In addition, the gamification mechanic "Sharing Knowledge (Ph2)" is significant and positively correlated with the activities Forum, Peer Assessment, and Wiki $(r=.309, r=.262, r=.257, p<.05$, respectively). These correlations can be considered small to medium (Cohen 2009). Finally, the mechanic "Purpose/Meaning" (Ph3) revealed a significant and positive correlation with the online learning activity Tutorial $(r=.248, p<.05$, respectively). This correlation can be rated as small (Cohen 2009) (Table 3).

Player. There is a significant and positive correlation between the gamification mechanic "(Virtual)Economy (P2)" and the online learning activity Task $(r=.213, p<.05$, respectively), and the correlation is small (Cohen 2009) (Table 3).

In sum, the results showed significant and positive correlations between the six online learning activities surveyed and at least one of the associated gamification mechanics of the five gamification user types (Table 3).

In the next step, the significant correlations that were found between the gamification mechanics and related user types and learning activities were visualized to describe two perspectives towards a motivational design. The first view is a person-centered perspective (Keller 2009), initially using the five gamification user types (step 1), their respective gamification mechanics (step 2), and finally, their relations to the six online learning activities (step 3) (Table 4). The perspective, which was environmentally centered (Keller 2009), illustrates the connections found between the six online learning activities, their associated gamification mechanics (step 2), and finally, their associated gamification user types (step 3) (Table 5). Using these different starting points and perspectives is advantageous for showing possible solutions for different kinds of instructional problems (Keller 2009). In addition, they support the derivation of conclusions from the results and recommendations for a motivational design in learning management systems.

$R Q$ (3). To answer the third research question, first, the person-centered perspective is described, and subsequently, the environmental perspective is reported (Tabs. 4 and 5).

A person-centered perspective (Table 4). The starting point of this view was to first examine the five gamification user types. They were then presented from the 
Table 4 A person-centered perspective of the results (user types 1-5)

\begin{tabular}{lll}
\hline $\begin{array}{l}\text { Gamification user type and its } \\
\text { motivation (step 1) }\end{array}$ & $\begin{array}{l}\text { Associated gamification } \\
\text { mechanic* (step 2) }\end{array}$ & $\begin{array}{l}\text { Associated online learning } \\
\text { activity* (step 3) }\end{array}$ \\
\hline (1) Socializer-relatedness & Social Discovery/Network (So1) & $\begin{array}{l}\text { Forum, Peer Assessment, Task, } \\
\text { Tutorial, Wiki }\end{array}$ \\
& Guilds/Teams (So2) & Peer Assessment, Wiki \\
& Social Pressure, pos. (So4) & Peer Assessment \\
(2) Free Spirit-autonomy & Exploration (FS2) & Quiz \\
(3) Achiever-competence & Level/Progression (A1) & Tutorial, Wiki \\
& Learning/New Skills (A2) & Wiki \\
& Unlockables/Rare Content (A4) & Tutorial \\
(4) Philanthropist-purpose & Care-Taking (Ph1) & Tutorial \\
& Sharing Knowledge (Ph 2) & Forum, Peer Assessment, Wiki \\
& Purpose/Meaning (Ph3) & Tutorial \\
\hline
\end{tabular}

*Data analysis showed significant correlations $(p<.05$, two-tailed)

perspective of their significant correlations with the gamification mechanics and the six online learning activities. This approach aims to clarify the specific learning preferences of the distance learners surveyed.

The gamification user type Socializer revealed connections to five of the six online learning activities. Students who agreed with this user type said that they would like to interact with others (So1) by using the features Forum, Peer Assessment, Task,

Table 5 An environment-centered perspective of the results (activities A-F).

\begin{tabular}{|c|c|c|}
\hline $\begin{array}{l}\text { Online learning activity* (step } \\
\text { 1) }\end{array}$ & $\begin{array}{l}\text { Associated gamification mechanic* } \\
\text { (step 2) }\end{array}$ & $\begin{array}{l}\text { Associated gamification user type } \\
\text { (step 3) }\end{array}$ \\
\hline \multirow[t]{3}{*}{ (A) Forum } & Social Discovery/Network (So1) & Socializer \\
\hline & Sharing Knowledge (Ph2) & Philanthropist \\
\hline & Gifting/Sharing (Ph4) & \\
\hline \multirow[t]{4}{*}{ (B) Peer Assessments } & Social Discovery/Network (So1) & Socializer \\
\hline & Guilds/Teams (So2) & \\
\hline & Social Pressure (pos.) (So4) & \\
\hline & Sharing Knowledge (Ph2) & Philanthropist \\
\hline (C ) Quiz & Exploration (FS2) & Free Spirit \\
\hline \multirow[t]{2}{*}{ (D) Tasks } & Social Discovery/Network (So1) & Socializer \\
\hline & (Virtual)Economy (P2) & Player \\
\hline \multirow[t]{5}{*}{ (E) Tutorial } & Social Discovery/Network (So1) & Socializer \\
\hline & Level/Progression (A1) & Achiever \\
\hline & Unlockables/Rare Content (A4) & \\
\hline & Care-Taking (Ph1) & Philanthropist \\
\hline & Purpose/Meaning (Ph 3) & \\
\hline \multirow[t]{5}{*}{ (F) Wiki } & Social Discovery/Network (So1) & Socializer \\
\hline & Guilds/Teams (So2) & \\
\hline & Level/Progression (A1) & Achiever \\
\hline & Learning/New Skills (A2) & \\
\hline & Sharing Knowledge (Ph2) & Philanthropist \\
\hline
\end{tabular}

*Data analyses showed significant correlations ( $p<.05$, two-tailed) 
Tutorial, and Wiki. In addition, these learners declared that they would like to work in teams (So2) as they learn using the activities Peer Assessment and Wiki. They also reported being more motivated when others watch them doing their work (So4). This motivational learning behavior was related to the online learning activity Peer Assessment. (2) Students who matched the description of Free Spirit identified with the activity Quiz and said that they would like to spend a great deal of time trying out things (FS2). (3) In the survey, the gamification user type Achiever was related to the online learning activities Wiki and Tutorial. In doing so, learners have the desire to see steady progress in the things they do (A1) and want to continue training to learn new skills (A2). These two learning behaviors revealed a connection with the activity Wiki. Furthermore, students of this user type said that they were motivated to work towards a specific learning objective (A4) and like to see progress in the things they do (A1) as they use the online learning activity Tutorial. (4) Learners who agreed with Philanthropist declared that they were happy if they can help others (Ph1), such that their motivational learning behavior is related to the activity Tutorial. They also would like to share their knowledge with others ( $\mathrm{Ph} 2)$ by using the activities Forum, Peer Assessment and Wiki. Learners of this user type also reported that things would be important to them when they had a deeper meaning or a benefit for the common good (Ph3). These learning preferences showed a connection to the online learning activity Tutorial. (5) Participants in the survey who agreed with the user type Player said they would weigh their actions objectively in order to always know how much they invest and what they need to attain (P2). This motivational learning behavior was revealed to be related to the online learning activity Task.

An environment-centered perspective (Table 5). To employ this perspective, the six online learning activities were considered first. Then, they were depicted with the significant correlations of gamification user types and mechanics. This approach is beneficial for steps towards the use of motivational strategies when planning instructions in learning management systems.

(A) The results of the study emphasized that the activity Forum is associated with learners who would like to interact with others, work in teams, and share their knowledge with their fellow students. (B) Subsequently, the activity Peer Assessment connects students with different motivational learning behaviors who would like to interact with others, work in teams, and share their knowledge and who are more motivated when others watch them doing their work. (C) The findings also revealed that students would like to spend time trying out things by using the activity Quiz. (D) Furthermore, the online learning activity Task is associated with learners who said that they would like to interact with others but would also weigh their actions to always know what they invest and what they need to attain. (E) In addition, the students in the study would like to use the activity Tutorial to interact with others, to see a steady progress in their learning, to work towards a specific learning objective. They also like to help others and see a deeper meaning in things. (F) Finally, the online learning activity Wiki is associated with learners who would like to interact, work in teams, continue their training, and share their knowledge with others.

\section{Discussion}

The findings in the present investigation revealed average levels of agreement with all five gamification user types surveyed (Socializer, Free Spirit, Achiever, Philanthropist, 
and Player) (Fig. 2). They could also be associated with all six online learning activities (Forum, Peer Assessment, Quiz, Task, Tutorial, and Wiki). This outcome of the study is important because it underlines the heterogeneity of online learners, who differ in age, experiences, interests, and learning preferences that are characteristic of distance education (Allen \& Seaman 2017).

The results were visualized from a person-centered perspective (Table 4) and an environment-centered perspective (Table 5) to identify the connections found in the survey and to clarify the solutions for different kinds of instructional problems (Keller 2009). In the following, the person-centered perspective is discussed first, and then, specific implications for the six online learning activities surveyed are derived from the environment-centered perspective towards a motivational design.

The person-centered perspective revealed that online learners reported a wide range of preferences and interests since all five user types were represented. This result is in line with earlier statements of Korbas (2015). The largest number of connected online learning activities in the study was found for the gamification user type Socializer. This result is not surprising since this type is motivated by relatedness and the desire to interact with others and many learning activities have an interactional quality. Learners who matched this user type would like to use various kinds of online learning activities and benefit from the different possibilities implemented in online learning platforms. In doing so, they show active online learning behavior. Koper (2015) also presented evidence of such learning behavior with active distance online learners who preferred to interact and collaborate online with their fellow students.

The results showed that the gamification user type Free Spirit had the least amount of related online learning activities and displayed a connection only to the activity Quiz. The other five online activities were indifferent to this user type. However, the finding of the associated learning activity Quiz is surprising since learners of this user type are motivated by autonomy and the desire to feel independent. In contrast to this learning preference, the activity Quiz contains particular rules and guided instructions that students need to follow in order to answer the questions correctly. This contradiction may be explained by the relation between autonomy and control, including "the [students'] ability to choose to cede control" (Anderson 2013, p. 93). This aspect reflects the learning situation in the context at hand since quizzes were a voluntary learning activity for the students. They had the opportunity to set their own pace, including to cease the activity without any consequences.

Next, the gamification user type Achiever is motivated by mastery and competence and had the highest average agreement for all participants in the survey (Fig. 2). In addition, it was related to two of the six online learning activities (Wiki and Tutorial). This is a crucial finding, as the low number of learning activities implies that the Achievers in the study carefully selected their online learning activities to focus clearly on their learning objectives and their learning progress. This result is in line with Salikina, Bin-Tahirb, and Emelia (2017), who found evidence of high-achieving students using specific learning strategies to accomplish their learning objectives that affect their learning motivation.

Then, the gamification user type Philanthropist was associated with the online activities Forum, Peer Assessment, or Tutorial in the study. This result is surprising, as it revealed that Philanthropist had many similarities with the user type Socializer in terms 
of their related online learning activities. However, the needs of this user type for motivational online learning are different. The user type Socializer has the desire to feel related to others. On the other hand, a Philanthropist is motivated to find purpose in their actions and to be altruistic. In the study, this user type had the second highest average agreement for all participants (Fig. 2) and was a relevant group of online learners in the context at hand. Their altruistic attitude, as determined in this study, could be of great advantage for online courses since learning strategies in web-based platforms such as Moodle become increasingly group-oriented (Hanna 2013). A Philanthropist can function as a moderator or tutor to support weaker students and help facilitate students' integration into group-oriented online learning (Marczewski 2015).

Finally, in the survey, an association was found between the user type Player and the online learning activity Task. This result revealed that these students want to invest only limited effort in online tasks and instead focus on their own benefits. In contrast to the other four gamification user types (Socializer, Free Spirit, Achiever, and Philanthropist), which are associated with intrinsic motivation (Table 1), the students who agreed with Player are extrinsically motivated and solve online problems not because they are interested in them but because they seek to receive acknowledgment or rewards for their actions. However, according to SDT (Deci \& Ryan 1985, 1993), extrinsic motivation can become internalized. Earlier findings of Bovermann et al. (2018) indicated that incentives and rewards with game element badges can be important factors to engage and intrinsically motivate students in online learning, especially when these rewards are perceived as acknowledgement from the students' facilitators.

Subsequently, the results from an environment-centered perspective (Table 5) have particular implications for the same settings. Integrating students' preferred motivational learning method and strategy in the design of online learning environments is consistent with the previous results of Jones and Blankenship (2017) or Zapalska and Brozik (2006). They concluded that students' online learning improved when the instructions provided are suitable for their learning preferences. To promote students' learning motivation, the following strategies and methods can be considered from the study's results for the six learning activities and connected gamification mechanics surveyed (Table 5):

(1) Forums should not only give students the opportunity to get in touch with others but also provide instructions for collaborative learning. In this way, students are motivated to apply and share their knowledge. (2) Then, peer assessments should support students' collaborative learning, allowing them to work in teams or groups. To foster positive social pressure among students, teamwork can be complemented by friendly competition with points and leaderboards (Kapp 2012, 2014; Werbach \& Hunter 2012). (3) Learners should be given time and freedom when using quizzes since they like to spend time trying things out, or as mentioned before, they might also choose to cease doing these online learning activities. (4) Next, tasks should be specified that are relevant to students to successfully complete their modules. To support their motivational learning behavior, it is beneficial to provide clear instructions and course objectives. In doing so, these learners can weigh their options and see how beneficial it is for them to work on their tasks. (5) Then, comprehensive information about the learning objectives of the course should be provided through tutorials. In combination with tutorials, students should also be able to monitor their progress through levels or progress bars 
(Kapp 2012; Werbach \& Hunter 2012). (6) Finally, students should use wikis to share their knowledge through instructions for teamwork and collaborative learning, as well as to learn new skills that they can practice.

\section{Conclusion}

The purpose of this survey was to explore connections between gamification user types (Marczewski 2015), associated gamification mechanics, and online learning activities for online distance learners in a bachelor's and master's degree program in educational science. The results provide insights that can have benefits to support a wider range of students in their online learning experiences and motivation. The review of Lameras et al. (2017) also highlighted the potential for classifying connections between learning attributes and gamification mechanics to enable students' motivation in online learning. The study's findings can provide a foundation for making decisions about instructional problems and provide valuable guidance towards a motivational design.

In addition, understanding the preferences and interests of the target group is important in order to purposefully design instructional concepts for online distance learners. Such an approach can help learners to more easily become engaged with their online learning activities (Hew et al. 2016; Werbach \& Hunter 2012).

Finally, the agreement with all five of the surveyed gamification user types revealed students' interests, preferences, and needs in the context at hand. The findings showed that most learners identified with one of the four user types that represent intrinsically motivated online learning behavior (Socializer, Free Spirit, Achiever, and Philanthropist; Table 1 and Fig. 2). However, a smaller group identified with Player, suited for extrinsically motivated learning behavior (Table 1 and Fig. 2). This gives further evidence that online distance learners represent a heterogeneous group and that instructional design must aim to meet their needs and learning motivation.

\section{Limitations}

Given the limited number of participants, general conclusions can only be made with caution. However, the findings do suggest a valuable foundation for designing motivational learning environments in online distance learning settings.

A limited number of online learning activities were chosen in the survey. Therefore, there could be relations to other online activities associated with the learning preferences and interests of online students. This limit in the activities studied was preferred to keep the design clear and simple and to provide opportunities for careful consideration.

\section{Future research}

The purpose of this study was to focus on the connections between the five gamification user types and the six online learning activities, therefore results were not broken down by age, gender, or academic qualification. These would be interesting parameters for future investigation.

Given the findings of this study, as a next step, empirical studies for further systematic research are recommended to confirm or expand the findings from both the person-centered and environment-centered perspectives. Since students' motivation is 
always a crucial factor in online learning, comprehensive results on gamification user types and gamification mechanics in the distance education context would be beneficial.

In addition, investigations focused on online learning activities other than those used in this study are recommended. It is suggested that the research also examines the association of online learning activities with gamification mechanics and related gamification user types. The findings may contribute to further steps with practical implications for motivational strategies in learning management systems in the context of distance education.

Finally, in this study, there were agreements between all gamification user types observed, and overlaps between the types could be very likely. Therefore, future research should focus on gamification of user types and their mixed forms. The results would be beneficial for a more detailed description of the target group regarding their learning preferences and motivational learning behavior.

Acknowledgements

Not applicable

\section{Authors' contribution}

The first author KB contributed to designing and conducting the study. This author performed the measurements and the analysis of the results and was involved in the writing of the manuscript. The second author TB supervised the project. Both authors read and approved the final manuscript.

\section{Funding}

Not applicable

\section{Availability of data and materials}

The data set is available under https://zenodo.org/record/3342499\#.XTGfBugzZnJ

\section{Competing interests}

The authors declare that they have no competing interests.

\section{Author details}

${ }^{1}$ FernUniversität in Hagen, Universitätsstraße 33, 58084 Hagen, Germany. ${ }^{2}$ Open University of the Netherlands, Valkenburgerweg 177, 6419 AT Heerlen, the Netherlands.

Received: 23 July 2019 Accepted: 19 December 2019

Published online: 10 January 2020

References

Allen, I. E., \& Seaman, J. (2017). Digital learning compass: Distance education enrollment report 2017. https:// onlinelearningsurvey.com/reports/digtiallearningcompassenrollment2017.pdf. Accessed 28 Aug 2018

Alsawaier, R. S. (2018). The effect of gamification on motivation and engagement. International Journal of Information and Learning Technology, 35(1), 56-79. https://doi.org/10.1108/IJILT-02-2017-0009

Anderson, W. (2013). Independent learning: Autonomy, control, and meta-cognition. In M. G. Moore (Ed.), Handbook of distance education (pp. 86-103). Routledge.

Bartle, R. (1996). Hearts, clubs, diamonds, spades: Players who suit MUDS. http://mud.co.uk/richard/hcds.htm. Accessed 29 Dec 2018.

Bekele, T. A. (2010). Motivation and satisfaction in internet-supported learning environments: A review. Educational Technology \& Society, 13(2), 116-127. https://www.jstor.org/stable/jeductechsoci.13.2.116 .

Bovermann, K., Weidlich, J., \& Bastiaens, T. (2018). Online learning readiness and attitudes towards gaming in gamified online learning - a mixed methods case study. International Journal of Educational Technology in Higher Education, 15(27), 1-17 https://doi.org/10.1186/s41239-018-0107-0.

Buckley, J., DeWille, T., Exton, C., Exton, G., \& Murray, L. (2018) A gamification-motivation design framework for educational software developers. Journal of Educational Technology Systems, 47(1), 101-127. https://doi.org/10.1177/ 0047239518783153

Chapman, J. R., \& Rich, P. J. (2018). Does educational gamification improve students' motivation? If so, which game elements work best? Journal of Education for Business, 93(7), 315-322 https://doi.org/10.1080/08832323.2018.1490687.

Clark, D. B., Tanner-Smith, E. E., \& Killingsworth, S. S. (2016). Digital games, design, and learning. Review of Educational Research, 86(1), 79-122 https://doi.org/10.3102/0034654315582065.

Cohen, J. (2009). Statistical power analysis for the behavioral sciences (2nd, reprint). Hillsdale, NJ: Erlbaum.

Deci, E. L., \& Ryan, R. M. (1985). Intrinsic motivation and self-determination in human behavior. Plenum.

Deci, E. L., \& Ryan, R. M. (1993). Die Selbstbestimmungstheorie der Motivation und ihre Bedeutung für die Pädagogik. Zeitschrift für Pädagogik, 39(2), 223-238. 
Deci, E. L., \& Ryan, R. M. (2000). The "what" and "why" of goal pursuits: Human needs and the self-determination of behavior. Psychological Inquiry, 11(4), 227-268. https://doi.org/10.1207/S15327965PLI1 104_01 .

Deci, E. L., \& Ryan, R. M. (2019). SDT: Self-determination theory. http://selfdeterminationtheory.org/ . Accessed 26 Nov 2019.

Deterding, S., Dixon, D., Khaled, R., \& Nacke, L. E. (2011). Gamification: Toward a definition. In Paper presented to CHI 2011, May 7-12, 2011 (pp. 1-4). ACM.

Diamond, L., Nacke, L. E., Tondello, G. F., Tscheligi, M., \& Marczewski, A. (2015). The HEXAD gamification user types questionnaire: Background and development process. http://blog.gamefulbits.com/publications/the-hexad-gamificationuser-types-questionnaire-background-and-development-process/. Accessed 22 Nov 2018.

Dichev, C., \& Dicheva, D. (2017). Gamifying education: What is known, what is believed and what remains uncertain: A critical review. International Journal of Educational Technology in Higher Education, 14(9), 1-36. https://doi.org/10.1186/s41239017-0042-5.

Dichev, C., Dicheva, D., Angelova, G., \& Agre, G. (2015). From gamification to gameful design and gameful experience in learning. Cybernetics and Information Technologies, 14(4), 80-100 https://doi.org/10.1515/cait-2014-0007.

Döring, N., \& Bortz, J. (2016). Forschungsmethoden und Evaluation in den Sozial- und Humanwissenschaften (5th ed.). Springer.

Dreimane, S. (2019). Gamification for education: Review of current publications. In L. Daniela (Ed.), Didactics of smart pedagogy (pp. 453-464). Cham: Springer. https://doi.org/10.1007/978-3-030-01551-0_23 .

Glass, A. (2014). The state of higher education 2014. http://www.oecd.org/education/imhe/StateofHigherEducation2014.pdf . Accessed 20 Aug 2018.

Hakulinen, L., Auvinen, T., \& Korhonen, A. (2015). The effect of achievement badges on students' behavior: An empirical study in a university-level computer science course. International Journal of Emerging Technologies in Learning, 10(1), 18-29. https://doi.org/10.3991/ijet.v10i1.4221 .

Hamari, J. (2015). Do badges increase user activity? A field experiment on effects of gamification. Computers in Human Behavior, 71, 469-478. https://doi.org/10.1016/j.chb.2015.03.036.

Hanna, D. E. (2013). Emerging organizational models in higher education. In M. G. Moore (Ed.), Handbook of distance education (pp. 684-694). Routledge.

Hartnett, M. (2016). The importance of motivation in online learning. In M. Hartnett (Ed.), Motivation in online education (pp. 5-32). Springer.

Hartnett, M. (2019). Motivation in distance education. In M. G. Moore \& Diehl, W. C. (Eds.), Handbook of Distance Education (4th ed., pp. 145 - 157). Routledge.

Hew, K. F., Huang, B., Chu, K. W. S., \& Chiu, D. K. W. (2016). Engaging Asian students through game mechanics: Findings from two experiment studies. Computers \& Education, 92-93, 221-236. https://doi.org/10.1016/j.compedu.2015.10.010

Huang, B., Hew, K. F., \& Lo, C. K. (2018). Investigating the effects of gamification-enhanced flipped learning on undergraduate students' behavioral and cognitive engagement. Interactive Learning Environments, 27(8), 1106-1126 https://doi.org/10. 1080/10494820.2018.1495653.

Hunicke, R., Leblanc, M., \& Zubek, R. (2004). MDA: A formal approach to game design and game research. In Proceedings of the challenges in games Al Workshop, nineteenth National conference of artificial intelligence (pp. 1-5). IEEE.

Jones, I. S.; \& Blankenship, D. (2017). Learning style preferences and the online classroom. Research in Higher Education Journal, 33. https://files.eric.ed.gov/fulltext/EJ1161492.pdf. Accessed 29 Mar 2019

Kahan, T., Soffer, T., \& Nachmias, R. (2017). Types of participant behavior in a massive open online course. The International Review of Research in Open and Distributed Learning, 18(6), 1-18 https://doi.org/10.19173/irrodl.v18i6.3087.

Kapp, K. M. (2012). The gamification of learning and instruction. San Francisco, CA: Pfeiffer.

Kapp, K. M. (2014). Game element: Core mechanic. http://karlkapp.com/game-element-core-mechanic/ . Accessed 11 Jan 2019.

Karra, S., Karampa, V., \& Paraskeva, F. (2019). Gamification design framework based on self determination theory for adult motivation. In L. Uden, D. Liberona, G. Sanchez, \& S. Rodríguez-González (Eds), Learning Technology for Education Challenges. LTEC 2019. Communications in Computer and Information Science (Vol 1011). Springer, Cham.

Karunanayaka, S. P., \& Naidu, S. (2017). Impact of integrating OER in teacher education at the Open University of Sri Lanka. In C. Hodgkinson-Williams \& P. B. Arinto (Eds.), Adoption and impact of OER in the Global South (pp. 459-498). https://doi. org/10.5281/zenodo.600398. Accessed 24 Mar 2019.

Keller, J. M. (2009). Motivational design for learning and performance: The ARCS model approach. Springer.

Kim, A. J. (2014). Beyond player types: Kim's social action matrix. https://amyjokim.com/blog/2014/02/28/beyond-player-typeskims-social-action-matrix/. Accessed 29 Dec 2018.

Kim, A. J. (2018). Game thinking: Innovate smarter \& drive deep engagement with design techniques from hit games. Gamethinking.io.

Kim, K.-J., \& Frick, T. W. (2011). Changes in student motivation during online learning. Journal of Educational Computing Research, 44(1), 1-23 https://doi.org/10.2190/EC.44.1.a.

Koivisto, J., \& Hamari, J. (2019). The rise of motivational information systems: A review of gamification research. International Journal of Information Management, 45, 191-210. https://doi.org/10.1016/j.jijnfomgt.2018.10.013 .

Koper, R. (2015). How do students want to learn in online distance education? Profiling student preferences. The International Review of Research in Open and Distributed Learning, 16(1), 307-329. https://doi.org/10.19173/irrodl.v16i1.2000

Korbas, S. (2015). Gamification User Types zur Unterstützung der Konzeption in der Softwareentwicklung. In A. Weisbecker, M. Burmester, \& A. Schmidt (Eds.), Mensch und Computer 2015. Workshopband (pp. 367-376). Oldenbourg Wissenschaftsverlag.

Lameras, P., Arnab, S., Dunwell, I., Stewart, C., Clarke, S., \& Petridis, P. (2017). Essential features of serious games design in higher education: Linking learning attributes to game mechanics. British Journal of Educational Technology, 48(4), 972994. https://doi.org/10.1111/bjet.12467.

Marczewski, A. (2015). Even ninja monkeys like to play: Gamification, game thinking \& motivational design. https://www. gamified.uk/even-ninja-monkeys-like-to-play/ . Accessed 3 Sept 2018.

Moodle (2018). About moodle. https://docs.moodle.org/35/en/About_Moodle. Accessed 19 Nov 2018.

Naidu, S. (2017). How flexible is flexible learning, who is to decide and what are its implications? Distance Education, 38(3), 269-272 https://doi.org/10.1080/01587919.2017.1371831. 
Park, J. H., \& Choi, H. J. (2009). Factors influencing adult learners'decision to drop out or persist in online learning. Educational Technology \& Society, 12(4), 207-217.

Paterson, S. M. (2014). Online learning communities: Motivational factors for success. International Journal of Recent Contributions from Engeneering, Science \& IT, 2, 6-12. https://doi.org/10.3991/ijes.v2i2.3812

Pechenkina, E., Laurence, D., Oates, G., Eldridge, D., \& Hunter, D. (2017). Using a gamified mobile app to increase student engagement, retention and academic achievement. International Journal of Educational Technology in Higher Education, 14(31), 1-12 https://doi.org/10.1186/s41239-017-0069-7.

Pink, D. H. (2012). Drive: The surprising truth about what motivates us. Riverhead Books.

Proulx, J.-N., Romero, M., \& Arnab, S. (2017). Learning mechanics and game mechanics under the perspective of selfdetermination theory to foster motivation in digital game based learning. Simulation \& Gaming, 48(1), 81-97 https://doi. org/10.1177/1046878116674399.

Qayyumn, A., \& Zawacki-Richter, O. (2019). The state of open and distance education. In O. Zawacki-Richter \& A. Qayyum (Eds. ), Open and distance education in Asia, Africa, and the Middle East: National perspectives in digital age (pp. 125 - 140). SpringerBriefs in Education.

Ryan, R. M., \& Deci, E. L. (2000a). Intrinsic and extrinsic motivations: Classic definitions and new directions. Contemporary Educational Psychology, 25(1), 54-67. https://doi.org/10.1006/ceps.1999.1020

Ryan, R. M., \& Deci, E. L. (2000b). Self-determination theory and the facilitation of intrinsic motivation, social development, and well-being. American Psychologist, 55(1), 68-78. https://doi.org/10.1037/0003-066X.55.1.68.

Ryan, R. M., \& Deci, E. L. (2017). Self-determination theory: Basic psychological needs in motivation, development, and wellness. The Guilford Press.

Sailer, M., Hense, J. U., Mayr, S. K., \& Mandl, H. (2017). How gamification motivates: An experimental study of the effects of specific game design elements on psychological need satisfaction. Computers in Human Behavior, 69, 371-380.

Sailer, M., \& Homner, L. (2019). The gamification of learning: A meta-analysis. Educational Psychology Review, 1-36. https://doi. org/10.1007/s10648-019-09498-w .

Salen, K., \& Zimmermann, E. (2004). Rules of play: Game design fundamentals. The MIT Press.

Salikina, H., Bin-Tahirb, S. Z., \& Emelia, C. (2017). The higher achiever students' strategies in English learning. Modern Journal of Language Teaching Methods, 7(11), 79-95.

Saputro, R. E., Salam, S. B., \& Zakaria, M. H. (2017). A review of intrinsic motivation elements in gamified online learning. Journal of Theoretical and Applied Information Technology, 95(19), 4934-4948.

Scheiner, C. W., \& Witt, M. (2013). The backbone of gamification: A theoretical consideration of play and game mechanics. In M. Horbach (Ed.), Informatik 2013 (pp. 2372-2386). Ges. für Informatik.

Schell, J. (2015). The art of game design: A book of lenses. CRC Press.

Simpson, O. (2013). Student retention in distance education: are we failing our students? Open Learning: The Journal of Open. Distance and e-Learning, 28(2), 105-119 https://doi.org/10.1080/02680513.2013.847363.

Utomo, A. Y., \& Santoso, H. B. (2015). Development of gamification-enriched pedagogical agent for e-Learning system based on community of inquiry. In Paper presented at the proceedings of the International HCl and UX Conference (CHluXiD '15), Indonesia.

van Roy, R., \& Zaman, B. (2018). Need-supporting gamification in education: An assessment of motivational effects over time. Computers \& Education, 127, 283-297. https://doi.org/10.1016/j.compedu.2018.08.018

van Roy, R., \& Zaman, B. (2019). Unravelling the ambivalent motivational power of gamification: A basic psychological needs perspective. International Journal of Human-Computer Studies, 127, 38-50. https://doi.org/10.1016/j.ijhcs.2018.04.009 .

Vogel, C., Hochberg, J., Hackstein, S., Bockshecker, A., Bastiaens, T. J., \& Baumöl, U. (2018). Dropout in distance education and how to prevent it. Proceedings of EdMedia: World Conference on Educational Media and Technology (pp. 1788-1799). Amsterdam, Netherlands: Association for the Advancement of Computing in Education (AACE). https://www. learntechlib.org/primary/p/184409/. Accessed 30 Sept 2018.

Werbach, K., \& Hunter, D. (2012). For the win: How game thinking can revolutionize your business. Wharton Digital Press.

Zapalska, A., \& Brozik, D. (2006). Learning styles and online education. Campus-Wide Information Systems, 23(5), 325-335. https://doi.org/10.1108/10650740610714080.

Zichermann, G., \& Cunningham, C. (2011). Gamification by design: Implementing game mechanics in web and mobile apps. O'Reilly Media.

\section{Publisher's Note}

Springer Nature remains neutral with regard to jurisdictional claims in published maps and institutional affiliations.

\section{Submit your manuscript to a SpringerOpen ${ }^{\circ}$ journal and benefit from:}

- Convenient online submission

- Rigorous peer review

- Open access: articles freely available online

- High visibility within the field

- Retaining the copyright to your article

Submit your next manuscript at $\mathbf{s p r i n g e r o p e n . c o m ~}$ 